\title{
Competitiveness of Travel Agencies in the European Tourism Market
}

\author{
Iris Mihajlović \\ University of Dubrovnik, Dubrovnik, Croatia
}

\begin{abstract}
The concept of competitiveness influenced by many factors is analyzed in terms of terminology distinctions. This is the reason of numerous definitions of this term included in the first part of the paper, which varies according to the aspect of the analysis, analyzed marketing unit, tourism product, geographical unit, region, destination, or entities that offer an acceptable integrated product a package by specific indicators for comparison of elements of competitiveness. The first part of the article theoretically emphasizes the distinction in defining the concept of competitiveness from various aspects of the analyzed market subjects (different features and facilities provided), and from those aspects of their specific business relationship in the market. Special contribution to the study of competitiveness is contained in the second part of the paper that analyzes the existing situation of intermediation in the European tourism market. This research is based on using the data of descriptive statistics and the secondary research which gives insights into the business of travel agencies, using the data such as number of employees, annual personnel costs, and the average annual cost per person employed in travel agencies in some European countries. The changes in the environment, and the competition initiate a need for an analysis of the internal environment, travel agencies' tasks, and their organizational structure. Also, the results conducted research on a sample of 500 travel agencies in 20 European countries indicate the dominance of quality service, price, and value for money as key factors of demand for achieving the competitiveness. It indicates new trends focused on needs for more specific - integrated tourist products that ensure the quality of service, value for money, and for the time that tourists invest in their obtaining.
\end{abstract}

Keywords: dynamic environment, intermediaries, competition, market, service quality, price

\section{Introduction}

In the era of regional development when the country (state) as a unit is no longer a primary geographical unit for creating and improving the competitiveness, the region has become the major driver of the economic development which is primarily conditioned by the availability of quality resources to run certain economic activities. A frequent focus on analysis of the competitiveness in tourism is a tourist destination, i.e., tourism product, whereby its competitiveness has been followed through tourism revenue, the power of attracting target market of tourist groups, the degree of satisfaction with the product/experience in the destination, the efficiency of using the superstructure and other resources of destination, profitability, the quality of life, and the preservation of

Iris Mihajlović, Ph.D., Senior Assistant, Department of Economics and Business Economics Dubrovnik, University of Dubrovnik.

Correspondence concerning this article should be addressed to Iris Mihajlović, Ph.D., University of Dubrovnik, Department of Economics and Business Economics Dubrovnik, Lapadska obala 7, 20000 Dubrovnik, Croatia. E-mail: iris.mihajlovic@unidu.hr. 
natural environment. Based on these criteria, it is possible to establish a system of indicators of market competitiveness on an intermediary which should integrate the specific features of the company competes, destinations, products and in the manner of speaking - the macro-destinations or sector, but also indicators of competitiveness which determine competitive position. In the context of monitoring competitiveness in tourism through competitive destinations and through the specificities of tourist products, it is partly contained the answer to the question why the analysis is not so often based on the competitiveness of tourism in a country.

\section{Literature Review}

Competitiveness is defined as the ability of long-term sustainable market participation under the market economy conditions that ensures unobstructed assumptions of competition among producers (Porter, 1979, pp. 137-145). Croatian Language Dictionary defines the competition as tender to achieve better performance and competitiveness as the "successfully handling" with the competition (Anić, 2003). The Organization for Economic Cooperation and Development (OECD) defined the competitiveness as a measure, by which the country, under the conditions of free market, can produce goods and services that meet the test of international markets while increasing the real income of the population in the long term (OECD, 2011).

From the above definitions, it is obvious that both in theory and practice, there are differences in defining the competitiveness of countries and the competitiveness of enterprises. In World Competitiveness Yearbook, competitiveness is defined as the ability of entrepreneurs to design, produce, and put into the market those products and services whose performance qualities are more attractive set of benefits than those offered by competitors (Garelli, 2011), and the competitiveness of the country, as the ability of generating more proportional riches than its competitors in world markets and this presence combination of resources and processes, whereby resources can be inherited or newly-created, until the processes transform resources into economic outcomes (Garelli, 2011). According to different definitions of the above, the determination of competitiveness and standards are defined differently for different objects (i.e., entrepreneurs, states, and sectors), as well as for different levels of competitive coverage (regional, national, or international level), and independence which performance indicators of economic business activity competitiveness are reported.

\section{Research of Competitiveness of Intermediation in the European Tourism Market}

Competitiveness of tourist market intermediation has been in the focus of interest of numerous international organizations. Thus, the World Travel \& Tourism Council (WTTC) supports the openness of the markets and also boosts competitiveness in tourism (WTTC, 2003) following the competitiveness on the market including the intermediation through "Tourism Competitiveness Monitor" from the year 2000 to 2007. World Economic Forum (WEF) monitors the competitiveness on the market of tourism mediation through the publication of "The Travel \& Tourism Competitiveness Report" that in an issue for the year 2011 includes the detailed information on 70 indicators in 139 countries (Blanke \& Chiesa, 2011). The World Center of Excellence for Tourism Destinations (CED) is an international non-profit organization established by the World Tourism Organization (UNWTO) in Montreal (Canada), with the main aim of developing competitive abilities in the destination. The analysis of market competitiveness of tourist intermediation could be applied to subjects of tourist intermediation (e.g., travel agencies, tour operators) related to other tourist subjects (e.g., hotels) as well as for different levels of coverage competitiveness (regional, national, or international level) (CED, 2013). It is necessary to define which economic performances are used to show the competitiveness of business for certain subjects and the levels that include 
competitiveness. Travel agencies and subjects of intermediation are also exposed to the competition and as such entities they have been extensively studied. The results of the research on the competitiveness of travel agencies in Hong Kong, which have been conducted by Wong and Kwan (2001, pp. 293-303), show that the increasing competitiveness can be achieved using different strategies, such as price competitiveness, enhance cooperation with business partners, and augment the efficiency of distribution channels.

\section{Data and Methodology}

Special contribution to the study of competitiveness is contained in the analysis of the existing situation of intermediation in the European tourism market. This research is based on using the data of descriptive statistics and the secondary research, using comparison method, which gives insights into the business of travel agencies in selected European countries in 2010. Research of sources of competitiveness in the internal environment of company is stated in the foundation based on using the data such as number of employees, annual personnel costs, and the average annual cost per person employed in travel agencies in some European countries. The purpose of mentioned indicators indicates the scope of competitiveness of performances in some business segments. The changes in the environment and the competition initiate a need for an analysis of the internal environment, travel agencies' tasks, and their organizational structure.

\section{Structural Changes and the Contribution on Analysis of Developmental Possibilities of the Intermediaries in the European Tourism Market}

The European Union gathers information on activities of travel agencies within Eurostat database. By the NACE Rev. $2^{1}$ classifications, the travel agency business activity belongs to section $\mathrm{N}$, which indicates the administrative and support services, and has a code N 79.11- Travel agencies (Engl. Travel agency activities). Eurostat structural business statistics describe the structure, main characteristics, and performances of economic activities in the European Union, elaborated in detail in several hundreds of sectors. Structural business statistics measure the economy by observing units engaged in the economic activity, i.e., companies. Table 1 shows the basic data on the operations of travel agencies in selected European countries in 2010.

Based on the number of travel agencies, developed tourist countries characterized by a large number of people, such as Germany and the United Kingdom and some receptive tourist countries, leaders in the world tourism, such as France and some Mediterranean countries (i.e., Spain and Italy) stand out.

Here the travel agency means the organizational unit that provides tourist intermediation (NACE Rev. 2 of 79.11) and benefits along with a certain degree of autonomy in decision-making, especially in the allocation of their own resources. This may be a sole legal unit that performs one or more activities at one or more locations. Figure 1 shows the number of travel agencies in the European countries in 2010. Total revenue includes accrued income from sales of products, goods, and services to the third parties, without Value Added Tax (VAT) to be deducted. Following items included: (1) all duties and taxes on the goods or services invoiced by the enterprise with the exception of the VAT calculated per unit vis-à-vis its customer and other similar deductible taxes directly linked to turnover; and (2) all other charges (transport, packaging, etc.) passed on to the customer, even if the costs are listed separately on the invoice. From this calculating it will be also excluded: (1) income classified as other operating income, financial income, and supplementary income in company accounts; and (2) operating subsidies received by public authorities or the institutions of the European Union.

\footnotetext{
1 The EU introduced the statistical classification of economic activities NACE Rev. 2. Its application started on January 1 st, 2008. The classification was published in the Commission Regulation of the European EU called Regulation (EC) No. $1893 / 2006$.
} 
According to the level of the total revenues of travel agencies, by far the most notable are the UK and Spain. Countries in which travel agencies generate revenue in excess of one billion EUR are Austria, Germany, Denmark, Italy, Netherlands, Norway, Portugal, and Sweden.

Table 1

Basic Data on the Operations of Travel Agencies in Selected European Countries in 2010

\begin{tabular}{|c|c|c|}
\hline Country & Number of travel agencies ${ }^{2}$ & Total revenue (mil Euros) \\
\hline Austria & 904.0 & $3,425.3$ \\
\hline Bulgaria & 360.0 & 38.6 \\
\hline Cyprus & 388.0 & 130.8 \\
\hline Germany & $6,930.0$ & $4,003.7$ \\
\hline Denmark & 164.0 & $1,060.4$ \\
\hline Estonia & 135.0 & 110.3 \\
\hline Spain & $7,638.0$ & $14,556.4$ \\
\hline Finland & 214.0 & 553.6 \\
\hline Croatia & $1,621.0$ & 508.6 \\
\hline Hungary & 363.0 & 144.3 \\
\hline Italy & $5,825.0$ & $4,949.7$ \\
\hline Letonia & 342.0 & 276.1 \\
\hline Luxembourg & 63.0 & \\
\hline Latvia & 370.0 & 161.8 \\
\hline Netherlands & $1,388.0$ & $2,107.7$ \\
\hline Norway & 386.0 & $2,549.3$ \\
\hline Poland & $1,684.0$ & 375.0 \\
\hline Portugal & $1,269.0$ & $2,517.6$ \\
\hline Romania & $2,291.0$ & 614.7 \\
\hline Sweden & 843.0 & $2,225.6$ \\
\hline Slovenia & 268.0 & 174.1 \\
\hline Slovakia & 160.0 & 60.2 \\
\hline United Kingdom & $4,210.0$ & $30,471.8$ \\
\hline
\end{tabular}

Note. Source: Prepared by the author according to the Eurostat, annual detailed enterprise statistics for services (NACE Rev. 2 HN and S95).

Table 2 shows the number of employees in travel agencies by countries in 2010, the number of persons employed per agency, the annual expenses of employees in millions of Euros, and the average annual expenses per employees in thousands of euros.

Within the context of structural business statistics, an employee ${ }^{3}$ is a person who works for an employer

2 According to the definition of the European Union, structural business statistics include all persons (including all organizations and business) registered for the activity of the statistical business register number of travel agencies covers (EU code 1110) number of legal and natural persons registered in the statistical business register that were active at least in some part of the reporting period.

3 An employee of the individual business unit receives a salary from the unit regardless of where the work is performed (even from a distant location). Worker from employment agency temporarily employed is considered to be an employee of the agency, and not of the business unit to which (he or she) is assigned. The following categories are also considered employees:

(1) Paid work of the owner;

(2) Students that formally contribute to the production unit in exchange for a fee and/or educational services;

(3) Employees who work under the contract that is specially created to stimulate hiring of unemployed person;

(4) Household workers - if there is an explicit agreement that persons receive a payment based on the work at home and if it is included in the salary. Those working part-time, seasonal workers, persons on strike or on the short-term leave are considered employees while volunteers or persons on long-term leave are not counted as employees. 
under a contract of employment and receives compensation in the form of salaries, wages, severances pay, or compensations in kind. A contract is an agreement between the company (employer) and the person (employee) that can be formal or informal, voluntarily signed by both parties, whereby the person working for a company as compensation gains money or in-kind benefits. Based on the number of employees, the countries with the highest total revenue and the largest number of travel agencies such as the UK, Germany, Netherlands, Spain, and Italy stand out. The number of employees per agency is also calculated, but there is no correlation between this indicator and other indicators. Figure 2 shows the number of employees per travel agency in European countries.

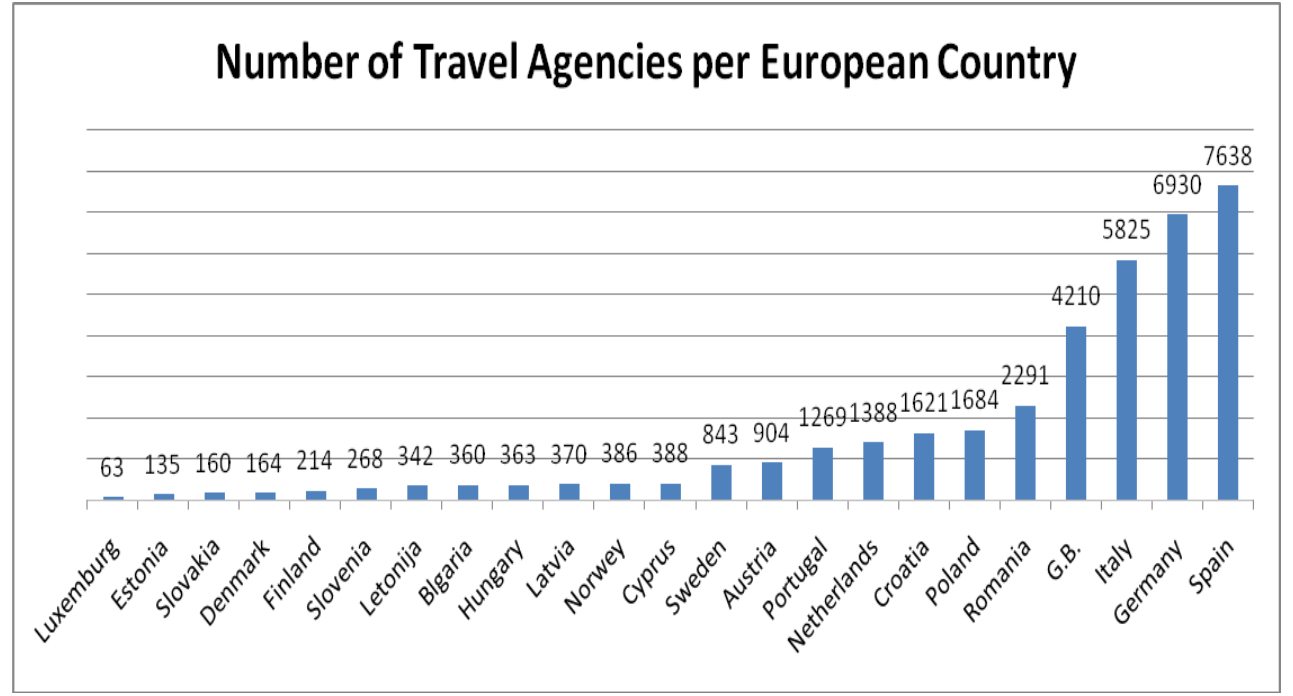

Figure 1. Number of travel agencies in European countries in 2010. Source: Prepared by the author according to the Eurostat, annual detailed enterprise statistics for services (NACE Rev. 2 HN and S95).

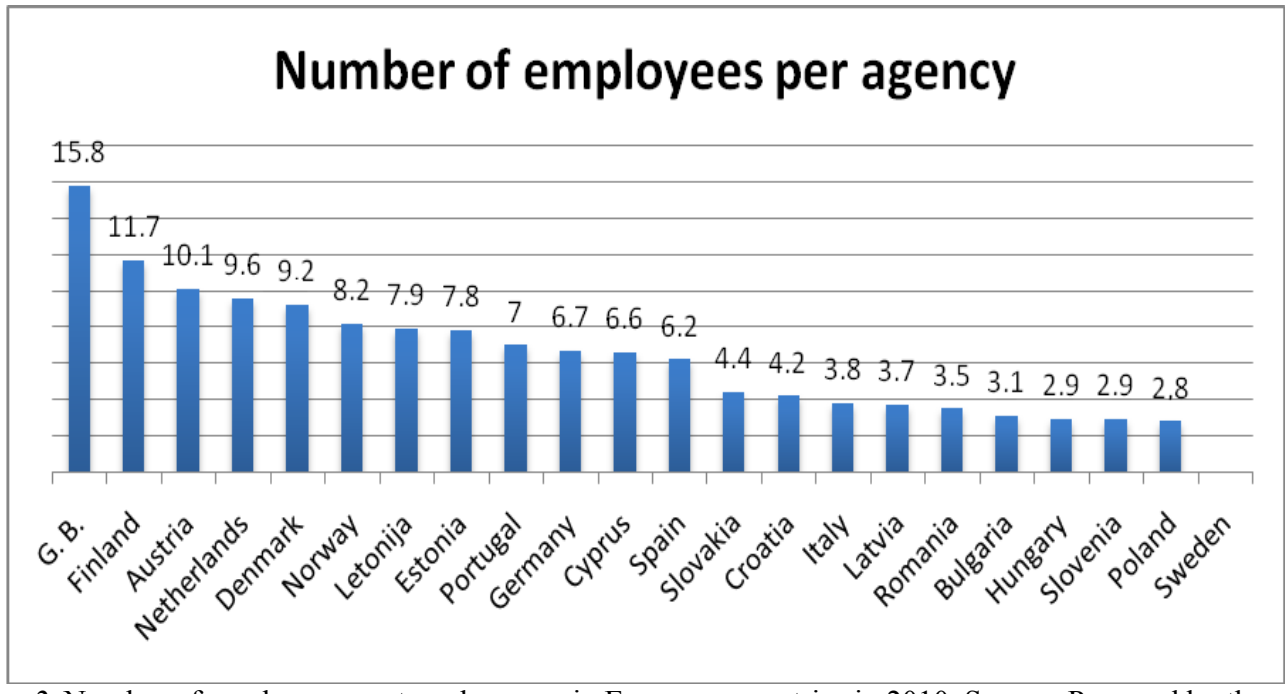

Figure 2. Number of employees per travel agency in European countries in 2010. Source: Prepared by the author according to the Eurostat, annual detailed enterprise statistics for services (NACE Rev. 2 HN and S95).

Expenses per employ can be defined as the total remuneration, in cash or in kind, payable by an employer to an employee (regular and temporary employees, as well as domestic workers) in return for the work done in the reference period. According to the expenses per employee, the UK, Germany, Netherlands, Spain, and Italy stand out. Figure 3 shows the average annual expenses per travel agency employee in the European countries in 2010. 
Table 2

Data on Employees of Travel Agencies of the European Countries in 2010

\begin{tabular}{|c|c|c|c|c|}
\hline Country & $\begin{array}{l}\text { Number of employed } \\
\text { persons }\end{array}$ & $\begin{array}{l}\text { Number of employed } \\
\text { persons per agency }\end{array}$ & $\begin{array}{l}\text { Annual expenses of } \\
\text { employees (mil Euros) }\end{array}$ & $\begin{array}{l}\text { Average annual expenses } \\
\text { per employee (000 Euros) }\end{array}$ \\
\hline Austria & 9,141 & 10.1 & 268.4 & 31.2 \\
\hline Bulgaria & 1,130 & 3.1 & 3.1 & 3.6 \\
\hline Cyprus & 2,552 & 6.6 & 51.2 & 20.6 \\
\hline Germany & 46,164 & 6.7 & $1,014.6$ & 26.4 \\
\hline Denmark & 1,505 & 9.2 & 77.7 & 53.0 \\
\hline Estonia & 1,055 & 7.8 & 15.2 & 14.8 \\
\hline Spain & 47,283 & 6.2 & $1,202.9$ & 28.0 \\
\hline Finland & 2,495 & 11.7 & 84.8 & 34.8 \\
\hline Croatia & 6,747 & 4.2 & 69.8 & 11.9 \\
\hline Hungary & 1,066 & 2.9 & 9.1 & 9.9 \\
\hline Italy & 22,159 & 3.8 & 448.3 & 30.5 \\
\hline Latonia & 2,710 & 7.9 & 23.0 & 8.7 \\
\hline Latvia & 1,366 & 3.7 & 9.2 & 6.8 \\
\hline Netherlands & 13,349 & 9.6 & 318.8 & 26.0 \\
\hline Norway & 3,176 & 8.2 & 151.5 & 48.8 \\
\hline Poland & 4,774 & 2.8 & 28.3 & 9.7 \\
\hline Portugal & 8,921 & 7.0 & 180.5 & 20.8 \\
\hline Romania & 7,966 & 3.5 & 32.2 & 4.2 \\
\hline Sweden & 6,980 & & 254.1 & \\
\hline Slovenia & 779 & 2.9 & 12.4 & 18.3 \\
\hline Slovakia & 699 & 4.4 & 4.4 & 6.3 \\
\hline \multicolumn{2}{|c|}{ United Kingdom 66,335} & 15.8 & $2,550.3$ & 39.9 \\
\hline
\end{tabular}

Note. Source: Prepared by the author according to the Eurostat, annual detailed enterprise statistics for services (NACE Rev. 2 HN and S95).

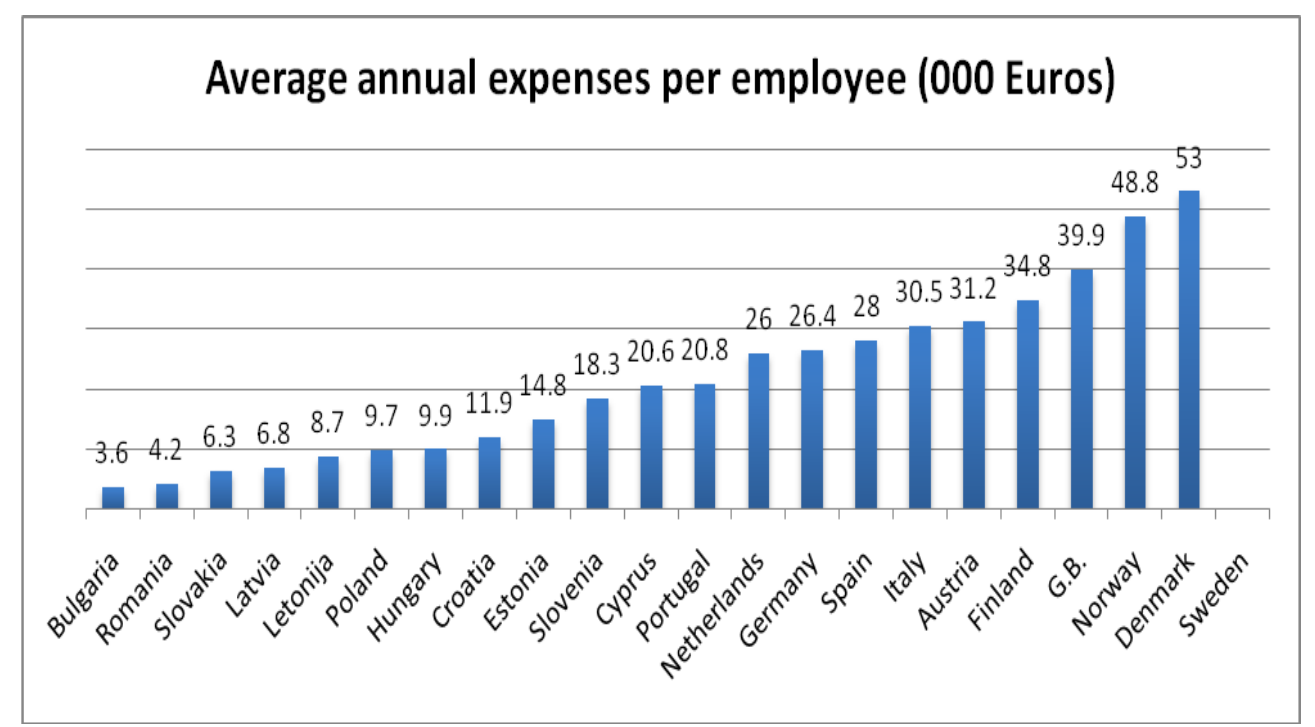

Figure 3. Average annual expenses per travel agency employee in the European countries in 2010. Source: Prepared by the author according to the Eurostat, annual detailed enterprise statistics for services (NACE Rev. 2 HN and S95). 
Table 3

The Most Important Challenges on the Operations of Travel Agencies

\begin{tabular}{llc}
\hline The challenges travel agencies face in their business & Number of response & Structure (\%) \\
\hline Increased competition & 297 & 53.90 \\
Administrative and regulatory burden & 233 & 42.30 \\
Taxes & 232 & 42.10 \\
Access to finance & 155 & 28.10 \\
Access to international markets & 88 & 16 \\
Lack of skills & 64 & 11.60 \\
Other & 55 & 10 \\
Environmental challenges & 42 & 7.60 \\
Access to information and know-how & 40 & 7.30 \\
\hline Note. Source: Response statistics for "SME panel questionnaire on tourism sector". Retrieved from \\
http:/ec.europa.eu/enterprise/sectors/tourism.
\end{tabular}

The presented data relating to the business of travel agencies within the EU indicate that there are strong differences in the number of travel agencies, their size in terms of number of employees and total revenue, as well as the expenses per employee. Mentioned differences directly influence the competitiveness of travel agencies, which come out from the ability to achieve market success of travel agencies and the competitiveness of tourism of each country.

\section{The Possibilities of the Travel Agencies Positioning in the Terms of Competitive Environment}

In conditions determined by changes in the internal and external environment, in order to analyze possibilities to achieve competitive ability, in the first quarter of 2009, the research was conducted on the sample of 500 travel agencies in 20 European countries. The results of this research show that the increased competition, i.e., a competition to achieve better results, is the most important "challenge" in business among the travel agencies.

However, the key to achieving competitiveness lies in three factors (see Table 4). According to travel agencies' managers, the most important factors in demand for their services are quality of service, price, and value for money.

Increasing the quality of service is the prerequisite to raise the level of competitiveness in the international tourism market and it is one of the main determinants for the establishment of strategic development plans in tourism. As some authors point out, the trend of overcoming low-cost strategy and directing it towards the policy of high value goes in this direction as well, thus improving the quality of tourism services. On the other hand, this strategy implies high investments, whose economic viability is questionable due to seasonality and the average lower level of capacity utilization.

According to the "Study on the Competitiveness of the EU Tourism Industry", it is expected that Europe will maintain its position as a leading tourist destination in the next decade, although it could lose some of its market share. Tourism is according to the authors of the study "highly fragmented value chain", which consists of large tour operators, hotel chains, and airlines, as well as small businesses that are also an integral part of the offer, where public and private institutions are often closely associated in providing quality services at the destination (European Commission, 2013). Trends that are placed before travel agents and subjects in tourist destinations are globalization, demographic change, easier access to information, more sophisticated customer requirements, sustainability, increased need for health, and wellness tourism with an increasing number of 
business models with minimal costs resulting in superior price competitiveness. Fight for survival in the global tourism market is fierce, and the creation of value becomes a critical success factor of travel agencies, service providers in the destination, as well as the destination itself.

Table 4

Key Factors in the Demand for Services of Travel Agencies

\begin{tabular}{|c|c|c|c|}
\hline Demand factor & Modality & Answer & Structure $(\%)$ \\
\hline \multirow{3}{*}{ Service quality } & Very important & 381 & 69.1 \\
\hline & Important & 153 & 27.8 \\
\hline & Less important & 17 & 3.1 \\
\hline \multirow{3}{*}{ Price } & Very important & 358 & 65 \\
\hline & Important & 174 & 31.6 \\
\hline & Less important & 19 & 3.4 \\
\hline \multirow{3}{*}{ Value for money } & Very important & 328 & 59.5 \\
\hline & Important & 187 & 33.9 \\
\hline & Less important & 36 & 6.5 \\
\hline \multirow{3}{*}{ Environmental issues } & Very important & 60 & 10.9 \\
\hline & Important & 231 & 41.9 \\
\hline & Less important & 260 & 47.2 \\
\hline \multirow{3}{*}{ Social issues } & Very important & 55 & 10 \\
\hline & Important & 214 & 38.8 \\
\hline & Less important & 282 & 51.2 \\
\hline \multirow{3}{*}{ Security issues } & Very important & 99 & 18 \\
\hline & Important & 176 & 31.9 \\
\hline & Less important & 276 & 50.1 \\
\hline
\end{tabular}

\section{Conclusions}

Quality restructuring of the tourism supply is under pressure of travel agencies which are in today's terms of fierce competition forced to offer not only quality and innovative service of their products (packages) but of other service providers (tourist subjects in the destination). They must guarantee the quality of service by bringing tourists into a relationship with the service providers which are ready to meet their specific requirements. This has always been a major test for the concept of mediating and organizational functions of travel agencies who base their business, to a greater or lesser extent, on such activities. Today it initiates need for an analysis of the internal environment, travel agencies' tasks, and their organizational structure. Flexibility that opens up the possibility of new products is promoted in the external environment through the creation of conditions for the possibility of new business partnerships, and integration with the same type of businesses that offer the same services, or partners who offer their own, often complementary services that complement the value of the tourist product. New trends are focused on demands for quality and more specific, innovated, and integrated tourism products. Research results suggest that specialization based on the following factors is extremely important in the further development of tourism agencies: (1) the quality factors as a reflection of specific preferences directed to the product; and (2) proportional value of services and prices as incentive of satisfaction of tourists, which also represents a way of increasing their competitiveness. 


\section{References}

Anić, V. (2003). Veliki rječnik hrvatskog jezika. Zagreb: Novi Liber.

Blanke, J., \& Chiesa, T. (2011). The travel and tourism competitiveness report. Retrieved from http://www3.weforum.org/docs/wef_traveltourismcompetitiveness_report_2011.pdf

Committee for Economic Development (CED). (2013). Centre mondial d'excellence des destinations, system of measures for excellence in destinations (SMED). Retrieved from http://www.ced.travel/en/our-services/service.html

European Commission. (2009). Study on the competitiveness of the EU tourism industry. Retrieved from $\mathrm{http} / /$ ec.europa.eu/enterprise/newsroom/cf/itemlongdetail.cfm?lang=en\&item_id=3702

European Commission. (2013). Enterprise and industry. Retrieved from http://ec.europa.eu/enterprise/sectors/tourism

Garelli, S. (2011). World competitiveness yearbook, Laussane, world competitevenss center. Retrieved from http://www.imd.org/research/publications/wcy/index.cfm

OECD. (2011). Competitiveness - Glossary of statistical terms. Retrieved from http://stats.oecd.org/glossary/detail.asp?id=399

Porter, M. E. (1979). How competitive forces shape strategy. Harvard Business Review, 57(2), 137-145.

Wong, K. F., \& Kwan, C. (2001). An analysis of the competitive strategies of hotels and travel agents in Hong Kong and Singapore. International Journal of Contemporary Hospitality Management, 13(6), 293-303.

WTTC. (2003). Tourism competitiveness monitor. $\quad$ Retrieved from http://www.wttc.org/eng/tourism_news/press_releases/press_releases_2003/latest_statistics/ 